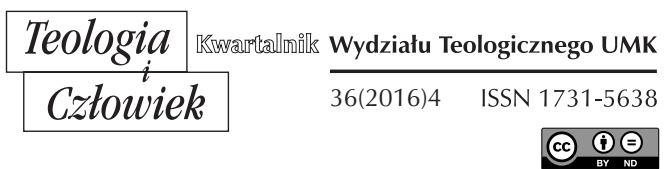

KS. MAREK FILIPCZUK*

WARSZAWA

\title{
JAKOŚĆ ŻYCIA - KWESTIA WCIĄŻ AKTUALNA
}

DOI: http://dx.doi.org/10.12775/TiCz.2016.044

Każdy człowiek otrzymuje od Boga w darze życie i powinien uczynić z niego coś dobrego. Wiele jest sposobów dobrego wykorzystania życia poprzez angażowanie w służbę ideałom ludzkim i chrześcijańskim. Chrystus oczekuje od swoich uczniów, aby wykorzystywali w apostolskiej i duszpasterskiej służbie ludzką inteligencje, naturalne siły, a także wiarę, miłość i świętość. Na drodze realizowania każdego powołania można spotkać trudności, ale miłość zbawcza potrafi przezwyciężyć każdą trudność. Prawdziwa odpowiedź na każde powołanie może wypływać tylko z głębokiej miłości dla Chrystusa. Tę siłę miłości Chrystus daje swoim uczniom jako dar, który dołączony jest do daru powołania i umożliwia dawanie świadectwa miłości przez całe życie ${ }^{1}$.

* Ks. Marek Filipczuk - kapłan diecezji warszawsko-praskiej, teolog moralista, doktor nauk teologicznych w zakresie teologii moralnej, wykładowca teologii moralnej na Wydziale Teologicznym Uniwersytetu Kardynała Stefana Wyszyńskiego w Warszawie (filipczuk17@gmail.com).

${ }^{1}$ Por. Jan Paweł II, Modlitwa, wezwanie, odpowiedź: trzy podstawy powołania. Orędzie na Światowy Dzień modlitw o powołania z 6 I 1979, w: Nauczanie Ojca Świętego Jana Pawła II. Komputerowy zapis dokumentów papieskich. Wersja 1.0, Wydawnictwo M, Kraków 1999, nr 3. 
Ewangelizacja obejmuje wszystkie wymiary życia człowieka, dlatego w jej realizacji nie wolno lekceważyć problemów, które dotyczą sprawiedliwości, wyzwolenia, postępu i pokoju w świecie ${ }^{2}$. Ewangelizacja musi zatem być bliska życiu, którego nie da się zatrzymać, by je poprawić lub niwelować skutki złego działania. Chrystus został posłany do ludzi w ich konkretnej sytuacji. Przebywał wśród biednych, schorowanych, opuszczonych, pogardzanych, aby ulżyć ich biedzie i przeciwstawiać się formom wykluczenia społecznego (por. Łk 4,18-19; Iz 61,1-2). Przyszedł, by wyzwolić człowieka. Dokonał tego, biorąc na siebie ludzkie słabości i brzemię cierpienia, którego częstą przyczyną jest choroba: „Istotnie, cała posługa Jezusa jest przeniknięta troską o cierpiących, których widział On wokół siebie: o ludzi zbolałych, paralityków, trędowatych, niewidomych, głuchych i niemych" (por. Mt 8,17) .

2 Por. tamże, 31. Jan Paweł II precyzując związek, jaki zachodzi pomiędzy ewangelizacją a postępem człowieka, czyli rozwojem i wyzwoleniem, podkreślał, że istnieją miedzy nimi wewnętrzne więzy. Na pierwszym miejscu jawi się związek natury antropologicznej, gdyż człowiek ewangelizowany nie jest bytem abstrakcyjnym, ale osobą, która uczestnicząc w życiu, jest uwikłana w sprawy społeczne i gospodarcze. Na drugim miejscu postawić należy więzy natury teologicznej, gdyż planu stworzenia nie można oddzielić od planu odkupienia, obejmującego również bardzo konkretne sytuacje, w których należy zwalczać krzywdy i zaprowadzić sprawiedliwość. I wreszcie są także więzy natury najbardziej ewangelicznej, czyli porządek miłości: nie można bowiem głosić nowego przykazania, nie popierając, wraz ze sprawiedliwością i pokojem, także prawdziwego i braterskiego postępu człowieka. Zob. J. Lewandowski, Drogi współczesnego człowieka do „źródta” życia, Warszawa 2004, s. 240-272.

3 Synod Biskupów, Specjalne Zgromadzenie poświęcone Afryce, Lineamenta 79. Zob. A. Lewek, Idea i sens nowej ewangelizacji, „Studia Theologica Varsaviensia” 32 (1994) z. 1, s. 45-107.Sens ewangelizacji bliskiej życiu człowieka widać najbardziej w Kościele „ubogim”, jakim jest np. Kościół w Afryce. Kościót musi nadal spetniać swa prorocka role $i$ być głosem tych, którzy nie maja głosu, aby wszędzie uznawano ludzka godność każdego człowieka oraz by człowiek stanowił zawsze centrum wszelkich programów władz państwowych. Synod [...] apeluje do sumienia rządzacych państwami i odpowiedzialnych $z a$ dobro społeczne, aby tworzyli coraz lepsze warunki dla wyzwolenia $i$ harmonijnego rozwoju ludności swoich krajów. W Kościele „ubogim” lepiej więc widać potrzebę głoszenia Ewangelii zarówno w imieniu Chrystusa, jak i w imieniu człowieka potrzebującego pomocy. Ten wymiar ewangelizowania w Kościele współczesnym został z różnych powodów pomniejszony, a tym samym ewangelizacja stała się bardziej przekazem słowa niż świadectwem życia. Zob. Jan Paweł II, Ecclesia in Africa. Posynodalna adhortacja apostolska o Kościele w Afryce i jego misji ewangelizacyjnej u progu Roku 2000 (1995), 


\section{PIERWSZEŃSTWO ŁASKI BOGA}

Już na samym początku warto zdać sobie sprawę z tego, że temat łaski, obok takich tematów, jak: prawda o Bogu i człowieku, grzechu czy rzeczach ostatecznych, należy do tematów naznaczonych pewnymi doktrynalnymi brakami w przekazie katechetycznym. W tym kontekście cenne wydaje się zwrócenie uwagi przez Jana Pawła II w liście apostolskim na nowe tysiąclecie chrześcijaństwa na temat miejsca i znaczenia łaski Bożej dla życia wiarą wyznawców Chrystusa. Nie ulega wątpliwości, że Jan Paweł II w wezwaniu skierowanym do wiernych pragnie uświadomić Kościołowi, że priorytet $\mathrm{w}$ programie na trzecie tysiąclecie stanowi prymat życia wewnętrznego, tj. pierwszeństwo świętości i modlitwy, będącego źródłem rozwagi i siły dla wszelkich ludzkich decyzji ${ }^{4}$. Powołanie do świętości urzeczywistnia się przez łaskę przybrania za synów ${ }^{5}$. Taka jest sytuacja człowieka żyjącego w świetle łaski: ma być wiarygodnym świadkiem, że Jezus Chrystus z miłości umarł za wszystkich i wszystkich powołał do uczestnictwa wraz z Nim w życiu Ojca. Aby mogła nastąpić odnowa życia modlitewnego w nowym tysiącleciu, potrzebna jest wiara, modlitwa i dialog z Bogiem, aby serce otworzyło się na strumień łaski a słowo Chrystusa mogło przeniknąć nas z całą swoją mocą. Człowiek stworzenie potrzebuje uświęcenia od Boga Stwórcy i Uświęciciela ${ }^{6}$.

Zasada pierwszeństwa łaski stanowi kluczową zasadę chrześcijańskiej wizji życia polegającej na tym, aby życie duchowe a także działalność duszpasterską oprzeć na Chrystusie, bez którego nic nie możemy uczynić? Tam, gdzie się mówi o zasadzie pierwszeństwa łaski, mówi się o pierwszeństwie Chrystusa. To On - Chrystus jest pierwszym, prawdziwym robotnikiem, o czym poucza nas św. Paweł w 1 Liście do Koryntian słowami: „My bowiem jesteśmy pomocnikami Boga, wy zaś jesteście uprawną rolą

w: Nauczanie Ojca Świętego Jana Pawła II. Komputerowy zapis dokumentów papieskich. Wersja 1.0, Wydawnictwo M, Kraków 1999, nr 70.

${ }^{4}$ Por. NMI 39.

${ }^{5}$ Por. J.M. Yanguas Sanz, Moralność cnót czy moralność obowiazków?, „Communio" 2000, nr 5, s. 9.

${ }^{6}$ Por. NMI 38; C. Ruini, Pierwszeństwo łaski. Refleksje nad Listem apostolskim „Novo millennio ineunte”, „L'Osservatore Romano” - wydanie polskie 2002, nr 7-8, s. 59.

7 NMI 38. 
Bożą i Bożą budowlą" (1 Kor 3,9). Bóg oczekuje od człowieka konkretnej współpracy z Jego łaską, aby w służbie Jego Królestwu wykorzystywał on wszystkie zasoby swej inteligencji i zdolności działania. A zatem jesteśmy wezwani przede wszystkim do współpracy z Bogiem: Jemu należy się bezwarunkowe pierwszeństwo. Kiedy ta zasada w życiu wiernych nie jest przestrzegana, nie może dziwić, że wszelkie ludzkie działanie kończy się niepowodzeniem, w sercu pozostawiając tylko obezwładniające poczucie frustracji ${ }^{8}$. Człowiek bowiem nie jest samo-wystarczalny, tylko Bogo-wystarczalny ${ }^{9}$.

List apostolski, o którym mowa, wielokrotnie wskazuje, w jaki sposób może się przejawiać prymat łaski. Jego najbardziej konsekwentnym wyrazem jest droga świętości, która w sposób konkretny ukazuje drogę ciągłego nawracania się dzięki umiejętności przezwyciężania własnego egoizmu i przyjęciu daru Bożego ${ }^{10}$. To nie grzesznik wysługuje sobie miłosierdzie przez swoją wędrówkę ku nawróceniu, ale to miłosierdzie kieruje go na drogę nawrócenia ${ }^{11}$. Człowiek sam $\mathrm{z}$ siebie nie jest $\mathrm{w}$ stanie nawiązać relacji z Bogiem, w jeszcze mniejszym stopniu coś Mu dać i w zamian coś otrzymać, a w żadnym wypadku nakładać na Niego zobowiązania będące wynikiem podejmowanych przez siebie wysiłków ${ }^{12}$. Nie można przecież sprowadzać chrześcijaństwa do poziomu religii czysto ludzkiej, zależnej jedynie od człowieczego trudu i inicjatywy. Uczynilibyśmy z chrześcijaństwa zwykły atletyzm moralny, gdybyśmy nie ukazali przesłania przekraczającego to, co możemy osiągnąć własnym tylko wysiłkiem ${ }^{13}$.

Sama wiara jest niczym innym, jak niezasłużonym darem (łaską), który, otrzymawszy, można tylko powitać z wdzięcznością ${ }^{14}$. Nawrócenie na wiarę zaczyna się zawsze poza człowiekiem; jest darem, ofiarowanym zawsze przez kogoś innego, przez Chrystusa, który wychodzi nam na

${ }^{8}$ Por. NMI 38; C. Ruini, Pierwszeństwo łaski. Refleksje nad Listem apostolskim „Novo millennio ineunte”, s. 58.

9 A. Siemieniewski, „Liczyć na moc Ducha”, „W drodze” 2002, nr 3, s. 11.

10 Por. C. Ruini, Pierwszeństwo łaski. Refleksje nad Listem apostolskim „Novo millennio ineunte", s. 59.

11 Por. Jan Paweł II, List do kapłanów na Wielki Czwartek 2002 r., Ząbki 2002, 6.

12 Por. J. Ratzinger, Granice dialogu, Kraków 1999, s. 47.

13 Por. tenże, Prawda i sumienie, „Ethos” 1991, nr 15-16, s. 183.

14 P. Góralczyk, Sumienie a prawda i wolność, „Communio” 2000, nr 1, s. 98. 
spotkanie ${ }^{15}$. Człowiek nie może sam uczynić się chrześcijaninem przez medytację lub moralną prawość, ponieważ wiara nie jest światopoglądem, lecz w pierwszym rzędzie przyjęciem samego Boga - Człowieka jako Osoby. Wiara jest przywiązana do prawdy, rozumianej jako osoba nie jako idea, dlatego naśladowanie Chrystusa to nie jest kwestia moralności, ale zagadnienie misteryjne - połączenie działania Bożego i ludzkiej odpowiedzi ${ }^{16}$. Moralność chrześcijańska nie zajmuje się przede wszystkim zaangażowaniem - wysiłkiem ludzkim, lecz działaniem Boga na rzecz przebóstwienia swoich dzieci; dopiero potem zwraca uwagę na osobiste zaangażowanie się człowieka pragnącego odpowiedzieć na Bożą życzliwośćc ${ }^{17}$. Stąd nie da się wiary oddzielić od miłości. Jeżeli dochodzi do związku człowieka i Boga, to może się to stać tylko poprzez wolną decyzję Boga, którego suwerenność pozostaje nienaruszona ${ }^{18}$. Oznacza to, że człowiek nabywa udziału w życiu Boga w taki sposób, że On sam daje mu możność posiadania Go. Tak więc łaska, należąc do porządku nadprzyrodzonego, wymyka się ludzkiemu doświadczeniu a także analizom psychologów i pedagogów; może być poznana jedynie przez wiarę w słowo Chrystusa ${ }^{19}$.

Człowiek nie potrafi o własnych siłach naśladować i przeżywać miłości Chrystusa. Staje się zdolny do takiej miłości jedynie mocą udzielonego mu daru. Darem Chrystusa jest Jego Duch, którego pierwszy owoc to miłość. Miłość Chrystusa jest w nas źródłem wszystkich naszych zasług przed Bogiem. Łaska jednocząc nas z Chrystusem czynną miłością, zapewnia nadprzyrodzona jakość naszym czynom ${ }^{20}$. Miłość nadaje pełny

15 J. Ratzinger, O naturze kapłaństwa, „Pastores” 1998, nr 1, s. 32.

16 Por. A. Frossard, Bronie papieża, Warszawa 1995, s. 46; J. Ratzinger, Nowa ewangelizacja, „L'Osservatore Romano” - wydanie polskie 2001, nr 6, s. 39.

17 J.M. Yanguas Sanz, Moralność cnót czy moralność obowiązków?, s. 10.

18 J. Ratzinger, Granice dialogu, s. 47.

19 Por. R. Guardini, Wolność - łaska - los, Kraków 1995, s. 146; S. Olejnik, Teologia moralna fundamentalna, Włocławek 1998, s. 268. „Łaska, należąc do porządku nadprzyrodzonego, wymyka się naszemu doświadczeniu i może być poznana jedynie przez wiarę. [...] Jednak, zgodnie ze słowami Chrystusa: „Poznacie ich po ich owocach” (Mt 7,20), rozważanie dobrodziejstw Boga w naszym życiu i w życiu świętych daje nam pewność, że łaska działa w nas i pobudza nas do coraz większej wiary oraz do postawy ufnego ubóstwa”. KKK 2005.

${ }^{20}$ Por. VS 22. Zob. KKK 2011. 
kształt ludzkiemu istnieniu i stanowi o jego doskonałości ${ }^{21}$. Jednakże miłości i życia zgodnego z Ewangelią nie można podejmować przede wszystkim w kategoriach nakazu, ponieważ ich wymogi przekraczają ludzkie siły: stają się one możliwe jedynie jako owoc daru ofiarowanego przez Boga, który, będąc obecny we wnętrzu człowieka jako myśl, sumienie, serce, uzdrawia i przemienia swoją łaską serce człowieka ${ }^{22}$. Dlatego w wychowaniu przez katechezę nie powinno się zapominać o tym, że człowiek jest kształtowany przez łaskę Bożą i że katecheza jest jedynie narzędziem jedynego Wychowawcy, którym jest Jezus Chrystus. Trzeba się uwolnić od pokusy myślenia, że to jedynie człowiek ze swej dobrej woli zdąża do Boga, by przez wypełnienie kultycznych zobowiązań podobać się $\mathrm{Bogu}^{23}$. Modlitwa, słuchanie słowa Bożego, sprawowanie sakramentów, w których następuje okazja do spotkania z łaską w formie czystej, a przede wszystkim niedzielna Eucharystia i sakrament pojednania to praktyki, dzięki którym najczytelniej możemy dostrzec działanie łaski ${ }^{24}$. Trzeba jednak uważać, by nie zacząć traktować sakramentu jako rodzaju dystrybutora łaski. Darem łaski są także przykazania Pańskie, powierzone człowiekowi tylko i wyłącznie dla jego dobra, aby strzec jego godności osobowej i prowadzić go do szczęścia, jak również sakramenty, w których spotkanie z łaską Bożą można nazwać świętowaniem, szczególną celebracją spotkania z Chrystusem ${ }^{25}$.

\section{MIŁOŚĆ PRAWDY - MlŁOŚĆ SŁUŻBY}

Dzięki pomocy łaski Bożej i przy współpracy ludzkiej wolności zawsze pozostaje dla człowieka otwarta duchowa przestrzeń nadziei ${ }^{26}$. Odwołanie się do łaski wymaga bowiem odniesienia do wolności i kon-

${ }^{21}$ Por. A. Solak, Sytuacja wychowawcza szkoły w kontekście katechezy, w: Katecheza wobec wyzwań współczesności, red. R. Czekalski, Płock 2001, s. 127.

${ }^{22}$ Por. DeV 54. Zob. także: VS 23.

${ }^{23}$ Por. J. Stefański, Liturgia źródłem i szczytem Kościoła, Gniezno 1993, s. 18.

${ }^{24}$ Por. C. Ruini, Pierwszeństwo łaski. Refleksje nad Listem apostolskim „Novo millennio ineunte", s. 59.

25 Por. EV 52; A. Siemieniewski, „Liczyć na moc Ducha”, s. 17.

${ }^{26}$ Por. VS 103. 
frontacji z nią. Jeśli więc z jednej strony spojrzenie w przyszłość pełne jest ewangelicznej nadziei, ponieważ widoczne jest działanie łaski Bożej, to $\mathrm{z}$ drugiej strony, biorąc pod uwagę osobistą wolność, trzeba czuwać, aby dokonywane przez człowieka wybory nie sprzeniewierzały się jej. Łaska przenika osobę, w miarę jak ona miłuje - czyli postępuje zgodnie ze sobą - i tylko na podstawie tej odpowiedzialności Bóg stwarza nas na nowo jako synów w Synu ${ }^{27}$. Dzieje się tak dlatego, że łaska uświęcająca jest w człowieku zasadą i źródłem nowego życia: życia Bożego, nadprzyrodzonego. U początku owego nadprzyrodzonego usynowienia ludzi stoi Duch Święty, który jest Miłością i Darem. Jako taki zostaje dany ludziom i w nadobfitości Daru nie stworzonego ma swój początek - w sercu każdego człowieka - ów najszczególniejszy dar stworzony: dar, poprzez który ludzie stają się uczestnikami Bożej natury. W ten sposób życie ludzkie zostaje przeniknięte uczestnictwem życia Bożego: uzyskuje Boski, nadprzyrodzony wymiar, stanowiący najwyższy w tym świecie wymiar ludzkiego istnienia. To współdziałanie $\mathrm{z}$ otrzymanym darem życia nadprzyrodzonego, świadoma współpraca z łaską Chrystusa, coraz dojrzalsze poznanie Boskiej miłości względem nas, coraz pełniejsze wewnętrzne zjednoczenie $\mathrm{z}$ Bogiem - to jest prawdziwe chrześcijańskie życie wewnętrzne ${ }^{28}$.

Świetlanym przykładem tak rozumianego życia wewnętrznego jest św. Józef. W nim urzeczywistnia się idealne przezwyciężenie pozornego napięcia między życiem czynnym i kontemplacyjnym. Józef przeżył zarówno miłość prawdy, czyli czystą kontemplacyjną miłość Boskiej Prawdy, która promieniowała w człowieczeństwie Chrystusa, jak i konieczność miłości, czyli równie czystą miłość służby, jakiej wymagała opieka nad tym człowieczeństwem i jego rozwój ${ }^{29}$.

Rozwój duchowy postępuje najbardziej wówczas, gdy człowiek współpracuje z łaską Bożą. Żeby zatem mógł następować nieustanny rozwój, całe życie człowieka powinno być życiem w łasce. Czy jednak człowiek skończony i grzeszny, może współdziałać z Bogiem, nieskończonym

27 Por. C. Ruini, Pierwszeństwo łaski. Refleksje nad Listem apostolskim „Novo millennio ineunte”, s. 58; J.M. Yanguas Sanz, Moralność cnót czy moralność obowiazków?, s. 10.

${ }_{28}$ Por. DeV 52; A. Santorski, Droga życia wewnętrznego, Warszawa 1997, s. 8.

${ }^{29}$ Por. RC 17. 
i świętym? Otóż tak, jest to możliwe właśnie dlatego, że sam Bóg stał się Człowiekiem, że przyjął ciało i wciąż na nowo poprzez swe Ciało zbliża się do nas, żyjących w ciele ${ }^{30}$. Zawsze jednak, mówiąc o więzi człowieka z Bogiem, należy dopowiedzieć, że są to partnerzy nierównorzędni ${ }^{31}$. Za pomocą łaski dokonuje się wewnętrzna jedność człowieka, scalenie, zespolenie tego, co Boże i tego, co ludzkie. Inaczej mówiąc, następuje integracja osobowości, która przez zerwanie pierwotnej więzi z Bogiem stała się pogmatwana, zbuntowana, skłócona z sobą wewnętrznie ${ }^{32}$. „Nieuwzględnienie tego, że człowiek ma naturę zranioną, skłonną do zła, jest powodem wielkich błędów w dziedzinie wychowania"33. Zaprzeczanie prawdziwym ludzkim ograniczeniom nie jest bowiem dobrym punktem wyjścia do budowania zdrowego szacunku dla siebie. Fundamentem prawdziwej dumy, podobnie jak prawdziwej pokory, jest prawda ${ }^{34}$.

Wielkie przeto znaczenie posiada łaska dla naturalnych dyspozycji człowieka, zwłaszcza gdy uświadomimy sobie wewnętrzne rozstrzelenie współczesnego człowieka, jego atomizację psychiczną i duchową ${ }^{35}$. Tym zaś, co prowadzi do całkowitej atomizacji ludzi pozbawionych oparcia $\mathrm{w}$ stałych wartościach, ludzi wykorzenionych z tradycji, religii i kultury; ludzi, których w wielu konsumpcyjnych zachodnich społeczeństwach już nic ze sobą nie łączy - poza walką o pieniądze i utrzymanie dobrobytu, jest ideologia postmodernizmu ${ }^{36}$. To poczucie arbitralności i fragmentaryczności doprowadziło do niepewności, zaś oferowanie ulotnych treści uświadomiło potrzebę powrotu do tego, co istotne. Ta świadomość zatomizowana, której konsekwencją jest postrzeganie siebie zarówno jednostkowe, jak i wspólnotowe, jako rzeczywistości rozbitej, pokawałkowanej i niespójnej, powoduje rozbicie, zgrzyt, rozklejenie, a to z kolei niezadowolenie, złośliwości, zgorzknienie, pretensje, rywalizację i urazy ${ }^{37}$. „Łaska

${ }^{30}$ Por. J. Ratzinger, Duch liturgii, Poznań 2002, s. 155.

31 Por. A. Siemieniewski, „Liczyć na moc Ducha”, s. 9.

32 Por. R. Guardini, Wolność - łaska - los, s. 143.

${ }^{33}$ KKK 407.

${ }^{34}$ Por. W.K. Kilpatrick, Psychologiczne uwiedzenie, Poznań 1997, s. 59.

35 Por. M. Quist, Modlitwa i czyn, Warszawa 1984, s. 181.

${ }^{36}$ Por. S. Wielgus, Kościół katolicki dziś. Zagrożenia, ich przyczyny oraz drogi wyjścia, „Nasz Dziennik”, 16-17 XI 2002, s. 14.

37 Por. C.M. Martini, Ludu mój, wyjdź z Egiptu, Kraków 1989, s. 15-16. 
nie niszczy natury, ale ją doskonali; przyzwolenie wiary, ogarniające rozum i wolę, nie niszczy, ale doskonali zdolność samodzielnego myślenia każdego człowieka wierzącego, który przyjmuje prawdy objawione"38. Pierwszeństwo łaski oznacza, że ona nie tylko nie niszczy natury, ale także jej nie neguje, wręcz przeciwnie: łaska buduje na naturze: Gratia suponit naturam $^{39}$. Tak więc oba te pojęcia doskonale mieszczą się $\mathrm{w}$ granicach naszego istnienia, noszącego wszakże jako całość zdecydowany charakter łaski ${ }^{40}$.

Człowiek stworzony przez Boga powinien być jednością, tak jak Bóg jest jednością. Ale przez to, że oddalił się od swojego Stwórcy, oddalił się również od wszelkiego stworzenia, od drugiego człowieka, a i tym samym siebie posiada coraz mniej. Dlatego jest potrzebne jest człowiekowi nawrócenie - metanoia oraz wiara w Ewangelię - Dobrą Nowinę ${ }^{41}$ Nawrócenie (metanoia) znaczy bowiem: uwolnić się od samowystarczalności, dostrzec i pogodzić się z tym, że potrzebujemy innych i Innego ${ }^{42}$. Łaska w chrześcijańskim znaczeniu tego słowa polega na tym, że Bóg przebacza człowiekowi jego winę, odkrywa przed nim swoją zakrytą prawdę, objawia mu swoją miłość, stwarza w nim zaczątek nowego życia. Nowo narodzony chrześcijanin to ktoś, kto został obdarzony łaską świętości, czyli łaską uświęcającą ${ }^{43}$.

Człowiek więc wplątany w walkę we zmaganiu z grzechem, posiłkując się głosem sumienia, wciąż musi się trudzić, aby trwać w dobrym i nie będzie mu dane bez wielkiej pracy oraz pomocy łaski Bożej osiągnąć jedności w samym sobie ${ }^{44}$. Sumienie uformowane przez wiarę i łaskę wie, że wszystkie dary pochodzą od jedynego Boga i Ojca oraz, że używać ich odpowiedzialnie i w pełni - to okazywać wdzięczność Bogu i realizować przykazanie miłości w codziennym czynie moralnym. Już bowiem samo

\footnotetext{
${ }^{38}$ FR 75.

39 A. Siemieniewski, „Liczyć na moc Ducha”, s. 15.

${ }^{40}$ Por. R. Guardini, Wolność - łaska - los, s. 139.

${ }^{41}$ Por. J. Kochel, Katecheza ewangelizacyjna w nauczaniu C. M. Martiniego,
} Opole 1999, s. 53.

42 Por. J. Ratzinger, Nowa ewangelizacja, s. 37.

${ }^{43}$ Por. R. Guardini, Wolność - łaska - los, s. 143.

${ }^{44}$ Por. DeV 44. 
przygotowanie człowieka na przyjęcie łaski jest dziełem łaski ${ }^{45}$. Stąd też w kształtowaniu sumienia ogromną rolę odgrywa nie tylko naturalny wysiłek danego człowieka, do zdwojenia którego prowadzi zresztą owocne przyjęcie łaski, ale przede wszystkim oddziaływanie czynnika nadprzyrodzonego na nasze sumienie ${ }^{46}$. Potrafi ona uzupełnić braki i przekreślić błędy w kształtowaniu sumienia. Może nawet dokonać całkowitego przeobrażenia źle, błędnie ukształtowanego sumienia. Sumienie na tej drodze kształtuje się przez modlitewny kontakt z Bogiem, który uwrażliwia nas na działanie łaski Bożej, usposabia do przyjęcia darów i natchnień Ducha Świętego. Jednocześnie dobra modlitwa pozwala nam lepiej poznawać siebie i w związku z tym bardziej skutecznie pracować nad własnym rozwojem duchowym. Osobiste obcowanie z Bogiem pozwala przyjąć prawdę o własnych słabościach bez tragizowania. Otwiera na przebaczenie i daje moc podejmowania nowych wyzwań. „W człowieku bowiem istnieje tęsknota, by obiektywnie sprawiedliwy wyrok sumienia o winie i niszczycielska męka wewnętrzna, która potem następuje, nie były czymś ostatecznym - by istniała plenipotencja łaski, siła pokuty, dzięki której wina znika, a prawda staje się rzeczywiście wybawiająca" ${ }^{47}$.

\section{EWANGELIZACJA - ZWYCZAJNE GŁOSZENIE SŁOWA BOŻEGO "W PORĘ I NIE W PORĘ"}

Wiara rodzi się i umacnia dzięki głoszeniu słowa Bożego. Uprzywilejowane miejsce i czas głoszenia widzimy w liturgii wszystkich sakramentów, najlepiej jednak w liturgii Eucharystii. Tym zaś, co w życiu Kościoła stanowi nadrzędne prawidło wyznawanej wiary, a także podstawowe źródło treści wiary, do którego Kościół odwołuje się w całej formacji chrześcijańskiej, jest Biblia ${ }^{48}$. Wszelkie chrześcijańskie wychowanie

${ }^{45}$ Por. P. Góralczyk, Sumienie a prawda i wolność, s. 98. „Bóg dopełnia w nas to, co zapoczątkował, 'bo zapoczątkowuje - sprawiając swoim działaniem, abyśmy chcieli, a dopełnia - współdziałając z naszą, już nawróconą, wolą"'. KKK 2001.

46 Por. M. Wolicki, Dojrzała osobowość, dojrzałe sumienie, Wrocław 2000, s. 144.

47 J. Ratzinger, Prawda, wartości, władza, Kraków 1999, s. 57.

${ }_{48}$ Por. KO 21; Z. Marek, Biblia $w$ katechetycznej posłudze słowa, Kraków 1998, s. 99. 
społeczne, wychowanie do odpowiedzialnego życia byłoby pozbawione fundamentu, gdyby nie opierało się na źródłach, nie zwracało się ku jego korzeniom - tj. Objawieniu ${ }^{49}$. Jeśli „katecheta ma być głosem, który odsyła do Słowa", to nie można on być katechetą bez Biblii, gdyż jest ona zawsze najlepszą i najbardziej substancjalną strawą ${ }^{50}$. Każdy chrześcijanin tę posługę katechisty zawsze i wszędzie zasadami moralnymi i stylem swojego życia winien spełniać. W realizowaniu tego zadania katechetą o największym zasięgu oddziaływania jest Kościól, który „jak najbardziej może ewangelizować świat za pomocą swego postępowania i obyczaju, tj. przez świadectwo potwierdzone życiem" ${ }^{51}$. Głos nauczający Kościoła, powołanego do ewangelizacji, jest dla sumienia sojusznikiem. Prowadzi on sumienie ku tej prawdzie, której rozum w swych najgłębszych warstwach szuka. Stąd przejrzystość sumienia ludzi Kościoła staje się dziś szczególnie ważnym świadectwem dla tych, którzy, opowiadając się za mglistymi wartościami konwencjonalnej i irenistycznej moralności ${ }^{52}$, odeszli od Kościoła, porzucając praktykowanie swojej wiary ${ }^{53}$.

Bez odwołania się do Pisma Świętego nie sposób wykładać prawd wiary, dlatego w przygotowaniu do pracy nauczycieli religii Pismo św. musi zajmować ważne miejsce ${ }^{54}$. Biblia jest bowiem dla katechety nieodłącznym i głównym podręcznikiem na wszystkich poziomach, albowiem liturgia, moralność, nauka społeczna Kościoła czy jego historia są ostatecznie zakorzenione w Biblii. Z niej czerpane są treści odsłaniające tajemnicę Boga. Zawiera ona i przekazuje zbawcze orędzie Boga, Jego troskę o rodzaj ludzki, aby wszystkim, którzy przez wytrwanie w dobrym szukają zbawienia dać żywot wieczny ${ }^{55}$.

49 Por. W. Kubik, W poczuciu odpowiedzialności za wychowanie religijne, „Horyzonty wiary" 1991, nr 7, s. 25.

${ }^{50}$ Jan Paweł II, Homilia z okazji jubileuszu katechetów i nauczycieli religii. Głoszenie Chrystusa waszym powołaniem, 2, „Katecheta” 2001, nr 4.

${ }^{51}$ EN 41.

${ }^{52}$ Por. J. Augustyn, Świat naszych uczuć, Kraków 2001, s. 161; Jan Paweł II, Głoszenie Chrystusa waszym powołaniem, 4.

${ }^{53}$ J. Augustyn, Świat naszych uczuć, s. 161.

${ }^{54}$ Por. W. Kubik, W poczuciu odpowiedzialności za wychowanie religijne, s. 26.

${ }_{55}$ Por. KO 3. 
Dokumenty Kościoła zachęcają, by odpowiedzi na pytania moralne szukać za pomocą Bibliij ${ }^{56}$. W tekście biblijnym nie należy jednak szukać odpowiedzi, niemal recepty, na wszystkie współczesne problemy i pytania związane z codziennym życiem człowieka, albowiem Pismo św. nie jest jakimś traktatem o życiu, o człowieku, o historii, ale głęboką rzeczywistością tego wszystkiego, niezmierzoną potęgą Boga, która wypełnia się i jest w niej obecna. Należy raczej doszukiwać się w nim wielkich dzieł Boga, które podnosiły i podnoszą na duchu ludzi, dodając odwagi, pomagając w dorastaniu do dojrzałej wiary. Pismo Święte bowiem jako księga słowa Bożego od czytelnika - słuchacza oczekuje wiary ${ }^{57}$. Współcześnie, z jednej strony potrzeba dążenia do dojrzałej wiary, a z drugiej świadkowie Jehowy, zmuszają nas do głębszego studiowania Pisma św. W Piśmie Świętym jest bowiem jakaś szczególna łaska i jakiś czar, którego nic nie zastąpi, bo słowo natchnione jest w Kościele na podobieństwo Eucharystii przedłużeniem Wcielenia i narzędziem Jego mocy działającej wśród nas. Dlatego musimy zbliżać się do Pisma świętego jak do Ciała Chrystusa ${ }^{58}$.

Ewangelizacja jest z pewnością jednym z najważniejszych zadań stojących przed Kościołem na progu nowego tysiąclecia ${ }^{59}$. Kościół wzywa do ewangelizacji wszystkich - nikogo nie odtrąca. W dziele coraz głębszego zrozumienia słowa Bożego, doskonalszego wyrażenia go i życia nim uczestniczy cały lud Boży. Najpierw jednak trzeba dać się samemu zewangelizować poprzez odnowienie wiary i nawrócenie, aby w ten sposób być skutecznym znakiem ewangelizacji ${ }^{60}$. Posługa słowa, będąc podstawowym elementem ewangelizacji, zobowiązuje chrześcijan, żeby karmili się słowem, by być sługami Słowa w dziele ewangelizacji ${ }^{61}$. Prawdziwa, szczera miłość zakłada bowiem uprzednie poznanie przedmiotu miłości i domaga się ciągłego wzbogacania wiedzy o tym, kogo się miłuje. Toteż również

56 Por. P. Tomasik, Nauczanie religii w publicznym liceum ogólnokształcacym wobec założeń programowych polskiej szkoły, Warszawa 1998, s. 113.

57 Por. A. Offmański, W kierunku katechezy ewangelizacyjnej. Polska katecheza młodzieżowa w latach 1945-2000, Szczecin 2000, s. 99.

${ }^{58}$ Por. E. Bianchi, Przemodlić słowo, Kraków 1999, s. 31-32.

59 Por. NMI 40.

${ }^{60}$ Por. W. Kawecki, Jubileusz chrześcijaństwa czasem odnowienia wiary $i$ świadectwa, „Homo Dei” 1999, nr 4, s. 92.

${ }^{61}$ Por. NMI 40. 
ci, którzy są już uczniami Chrystusa, potrzebują stałego karmienia się słowem Bożym, by wzrastać w swoim życiu chrześcijańskim. „Kiedy wiara nie jest dostatecznie karmiona słowem Bożym, kiedy powstaje sprzeczność pomiędzy tym, w co się wierzy i tym, czym się żyje, wówczas wierzący tracą zdolność oddziaływania na społeczeństwo"62.

Pismo Święte jest mową utrwaloną pod natchnieniem Duch Świętego na piśmie, a święta Tradycja przekazuje je w całości ich następcom, by oświeceni Duchem prawdy, wiecznie je w swym nauczaniu przechowywali, wyjaśniali i rozpowszechniali63. Przepowiadanie słowa Bożego, do głoszenia którego szczególnie powołany jest każdy kapłan, jako autentyczny przewodnik wspólnoty i prawdziwy szafarz Bożych tajemnic, ma zmierzać do tego, aby człowiek spotkał Jezusa, zwłaszcza w tajemnicy Eucharystii, będącej żywym sercem Kościoła ${ }^{64}$ i stanowiącej niewyczerpane źródło świętości i uwielbienia ${ }^{65}$. Dzięki słowu człowiek zostaje postawiony w sytuacji decyzji wobec wezwania Bożego. Przepowiadanie Kościoła służy zatem wewnętrznemu rozwojowi człowieka, ponieważ ukierunkowane jest na stworzenie wspólnoty życia z Bogiem. Chrystus dzięki biblijnemu ujęciu katechezy staje się centrum i treścią całego nauczania ${ }^{66}$. Jezus Chrystus nie tylko przekazuje słowo Boże, ale On jest słowem Bożym, jedynym, doskonałym i ostatecznym Słowem Ojca ${ }^{67}$. „Jezus jest Słowem Bożym, które stało się człowiekiem dla zbawienia wszystkich"68. Jedynym i wszechogarniającym Słowem jest Słowo Żywe, a więc Chrystus.

Kto prawdziwie spotkał Chrystusa, nie może zatrzymywać Go dla siebie, ale winien Go głosić z ufnością przedkładając wszystkim Jego propozycję ${ }^{69}$. Dziś skończył się czas chrześcijan letnich, niezdecydowanych, a przyszedł czas na ludzi gorących, na „gwałtowników porywających

${ }^{62}$ Jan Paweł II, Droga do dojrzałej wiary. Homilia wygłoszona do wiernych diecezji Nola (23 V 1992), 6, „L'Osservatore Romano” - wydanie polskie 1992, nr 7.

${ }^{63}$ DeV 9-10.

${ }^{64}$ Por. Jan Paweł II, Dar i tajemnica, Kraków 1996, s. 88.

${ }^{65}$ Por. VS 107.

${ }^{66}$ Por. P. Tomasik, Nauczanie religii w publicznym liceum ogólnokształcacym wobec założeń programowych polskiej szkoły, s. 113.

${ }^{67}$ Por. KKK 65.

${ }_{68}^{6}$ DI 15.

${ }^{69}$ Por. NMI 40. 
Królestwo Boże”, na ludzi bezwzględnie prawych, uczciwych, wiernych Bogu, niepaktujących ze złem, ofiarnych i heroicznie okazujących miłość bliźniego ${ }^{70}$. Zauważany współcześnie rozwój niewiary i obojętności religijnej jest właśnie wyzwaniem dla chrześcijan i apelem o bardziej intensywną wiarę. Każdy z nas i Kościół jako taki nie ma możliwości wyboru czasu i miejsca, w którym miałby dawać świadectwo wierze. Musimy starać się czynić to jak najlepiej w czasie, który został nam dany ${ }^{71}$. W każdych okolicznościach i w każdym środowisku, sprzyjającym lub niechętnym, należy odważnie głosić Ewangelię Chrystusa ${ }^{72}$. „Nasza misja każe nam być odważnymi świadkami Chrystusa w czasach współczesnych”73.

\section{GłOSZENIE „DOBREJ NOWINY" CODZIENNOŚCIA}

Ewangelizacja to nie tylko forma nauczania, ale przede wszystkim forma życia ${ }^{74}$. Dlatego brak świadectwa życia chrześcijan bywa nieraz dla tych, którzy z różnych powodów porzucają praktykowanie swojej wiary, negatywnym potwierdzeniem ich osobistej niewierności sumienia. Odbierają oni błędy moralne ludzi Kościoła jako usprawiedliwienie własnej moralnej słabości ${ }^{75}$. Nie można zatem lekceważyć zgorszenia z powodu

${ }^{70}$ Por. S. Wielgus, Kościót katolicki dziś. Zagrożenia, ich przyczyny oraz drogi wyjścia, s. 16.

${ }^{71}$ Por. R.J. Neuhaus, Człowiek nie jest skazany na klęskę, „Fronda” 2000, nr 21-22, s. 178.

${ }_{72}$ Por. Jan Paweł II, Głoszenie Chrystusa waszym powołaniem, 4.

${ }^{73}$ Przesłanie końcowe Światowego Kongresu Katolików Świeckich. Czujemy się odpowiedzialni za formacje i wychowanie $w$ wierze, „L'Osservatore Romano” - wydanie polskie 2001, nr 2, s. 42.

${ }^{74}$ Por. S. Wielgus, Kościót katolicki dziś. Zagrożenia, ich przyczyny oraz drogi wyjścia, s. 16. „Kościół otrzymał Ewangelię jako orędzie oraz źródło radości i zbawienia. Otrzymał ją w darze od Jezusa, posłanego przez Ojca, aby „ubogim niósł dobrą nowinę” (Łk 4,18). Otrzymał ją za pośrednictwem Apostołów, przez Niego posłanych na cały świat (por. Mk 16,15; Mt 28,19-20). W Kościele zrodzonym z tego głoszenia Ewangelii nieustannie rozbrzmiewa echo przestrogi Apostoła: „Biada mi, gdybym nie głosił Ewangelii” (2 Kor 9,16)". EV 78.

${ }^{75}$ Por. J. Augustyn, Świat naszych uczuć, s. 161-162. 
braku świadectwa ${ }^{76}$. Żeby nie dawać okazji do tego typu usprawiedliwień, prawdziwy apostoł musi być transparentny, musi być jak czysta szyba, aby przez jego słowa, przez jego pracę i przez całe jego życie ludzie mogli, tak jak przez szybę, dostrzec Chrystusa ${ }^{77}$. W Kościele bowiem za pierwszy środek ewangelizowania należy uważać świadectwo życia prawdziwie i ściśle chrześcijańskiego ${ }^{78}$. Ludzi naszych czasów nie można nakłonić do przyjęcia chrześcijańskiego orędzia oddziałując na nich wyłącznie przez nieustanne powtarzanie słowa lub przez kulturę, ale można ich poruszyć przez osobiste spotkanie. Dlatego ważne jest, aby rozmowa z ludźmi niewierzącymi na temat wiary nie była tylko pouczeniem o wierze, odpowiedzią na pytania o zasady wiary, ale przede wszystkim dzieleniem się własnym doświadczeniem wiary ${ }^{79}$. „Nowa ewangelizacja ujawnia swą autentyczność i równocześnie wyzwala cały swój dynamizm misyjny, jeśli dokonuje się nie tylko przez dar słowa głoszonego, ale także przez dar słowa przeżywanego" ${ }^{80}$. Zetknięcie się z rzeczywistością zbawczą poprzez głoszone słowo - stawia człowieka w sytuacji wyboru i wspiera go w odważnym podejmowaniu decyzji zgodnych z Ewangelią. Słowo Boże będąc darem życia i mając w sobie zdolność budzenia życia, ma za zadanie doprowadzić do nawrócenia, a także wywołać nową gorliwość i apostolski zapał do świadczenia o Chrystusie wobec świata ${ }^{81}$.

${ }^{76}$ Por. Komitet do Spraw Dialogu z Niewierzącymi Rady Konferencji Episkopatu Polski do Spraw Dialogu Religijnego, Niewierzacy w parafi - sugestie duszpasterskie, „Wiadomości KAI” z 8 VII 1999 r., s. 19.

77 Por. S. Wielgus, Kościót katolicki dziś. Zagrożenia, ich przyczyny oraz drogi wyjścia, s. 16.

${ }_{78}$ Por. EN 41.

79 Por. Komitet do Spraw Dialogu z Niewierzącymi Rady Konferencji Episkopatu Polski do Spraw Dialogu Religijnego, Niewierzacy w parafi - sugestie duszpasterskie, „Wiadomości KAI” z 8 VII 1999 r., s. 19.

${ }^{80}$ VS 107.

${ }^{81}$ Por. A. Offmański, W kierunku katechezy ewangelizacyjnej, dz. cyt., s. 212. Trafnie określił tę funkcję motywacyjną N. Lobkowicz: „Kościół winien mocniej ukazać, że naprawdę kocha człowieka, także i właśnie grzesznego - jak sam Zbawiciel; powinien tez starać się tak przekazywać swe orędzie, aby było ono przyjmowane jako wypełnienie najgłębszych i najbardziej ukrytych pragnień ludzkich. Kościół winien wciąż na nowo «zachwycać» Jezusem, a Jego samego i Jego orędzie ukazywać w tym «kosmicznym» wymiarze, w jakim On i ono występują". N. Lobkowicz, Przekazywanie wiary, w: Podstawy wiary. Teologia, Kolekcja „Communio”, t. 6, Poznań 1991, s. 209. 
Gdy w wierze zostajemy faktycznie obdarzeni miłością Boga i jego prawdą, to wtedy wynika $\mathrm{z}$ tego z koniecznością, że owa prawda chce być komunikowana i że jest ona czymś, co jest ważne dla wszystkich ludzi. Tylko głębokie przeżycie przylgnięcia do Chrystusa i przyjęcia Jego bezgranicznej miłości jest w stanie zainspirować do odważnego dawania świadectwa i nadać mu ewangeliczną świeżość, która może zachwycić świat ${ }^{82}$. Dzielenie się wiedzą o Bogu jest okazywaniem miłości, ponieważ wiedza w rozumieniu biblijnym zakłada miłość. A kochać można tylko w wolności. Dlatego moja decyzja, moje zbawienie nie mogą być gotowymi rzeczami, lecz miłość Chrystusa jest siłą, która chce mnie pociągnąć ku miłości, ale bez jakiegokolwiek przymusu ${ }^{83}$.

Zachodzą współcześnie sytuacje, nawet w krajach od dawna ochrzczonych, w świetle których wiara jest ciągle wystawiana na konfrontację i próbę. Wobec powyższych faktów koniecznością staje się katecheza przeniknięta duchem ewangelicznym. Katecheza ta inspiruje adresatów do autentycznego nawrócenia, pogłębia w nich doświadczenie Boga i przekonuje o życiowej wartości orędzia chrześcijańskiego. Konsekwencją wprowadzania takiej katechezy jest dialog z otaczającym światem, wyposażenie młodzieży w nadprzyrodzoną motywację i odwagę $\mathrm{w}$ realizowaniu apostolskiego świadectwa i podejmowania misji ewangelizowania świata. Nic bowiem nie wielbi bardziej Boga i nic nie jest bardziej potrzebnego dla współczesnego świata niż formowanie chrześcijan, którzy byliby prawdziwymi cognitores Dei - znawcami Boga. Dzielenie się z innymi wiedzą o Bogu jest najbardziej wysublimowaną postacią chrześcijańskiego miłosierdzia ${ }^{84}$.

Katecheza biblijna o postawach moralnych czy też o pojednaniu jest zawsze odnoszona nie tylko do nauki, ale i do osoby Chrystusa, który nie tylko działał, ale wciąż działa w swoim Kościele. Dlatego nie ma ona prowadzi jedynie do intelektualnej wiedzy o Chrystusie i Jego Ewangelii, o zasadach postępowania zaproponowanych przez Niego, ale także budzić postawę wiary, przylgnięcia do Chrystusa, który tu i teraz obdarza

${ }^{82}$ Por. A. Offmański, W kierunku katechezy ewangelizacyjnej, s. 209-210.

${ }^{83}$ Por. J. Ratzinger, O nihilizmie, piekle i kryzysie w Kościele, „Fronda” 1999, nr $15-16$, s. 12

${ }^{84}$ Por. J. Kochel, Katecheza ewangelizacyjna w nauczaniu C. M. Martiniego, s. 101. 
nas swoją łaską i przychodzi nas zbawić, jest obecny w swoim Słowie, w sakramentach, w modlitwie. Wierzyć w Chrystusa znaczy bowiem naśladować Go. Dlatego to takie ważne, by współczesny człowiek nie tylko dobrze postępował, ale także by uwierzył w Chrystusa ${ }^{85}$.

Kościół nie potrzebuje żadnego public relations, ma prawdę i Ewangelię $e^{86}$, która jest jedynym lekarstwem na barbarzyństwo czasów i rozmytych wartości. Kościół nie potrzebuje reklamy, potrzebuje raczej świadectwa, świętości wiernych. Doświadczenie wiary zawsze bowiem potrzebuje pośrednika, który będzie także świadkiem wiary ${ }^{87}$. W obliczu takich potrzeb Jan Paweł II w cytowanym już dokumencie Novo millennio ineunte apeluje o potrzebę nowego rozmachu w apostolstwie, które miałoby być przeżywane jako codzienne zadanie wspólnot, i o krzepiącą postawę grup młodzieżowych. Trzeba bowiem ten zapał do nowej aktywności misyjnej w młodych docenić i zainwestować $\mathrm{w}$ ich entuzjazm, aby dawali swą postawą świadectwo wielkoduszności i gotowości do służby ${ }^{88}$. Będzie jednak konieczne do tego dzieła użycie takiego języka przekazu Ewangelii, który będzie zrozumiany przez współczesnego człowieka żyjącego w nowej rzeczywistości przełomu tysiącleci. Szczególnie pożądane jest więc, aby w ewangelizacji uwzględnić mentalność i sposoby wzajemnego komunikowania się adresatów Ewangelii i jej przekazicieli ${ }^{89}$.

\section{WIERNOŚĆ EWANGELII WARUNKIEM AUTENTYCZNOŚCl CHRZEŚCIJANINA}

Przy uwzględnieniu nowych potrzeb nadal charakterystyczną cechą ewangelizacji pozostaje jednak wierność Radosnej Nowinie przez promulgowanie autentycznego kerygmatu, który winien stać się centralną treścią katechezy i to w taki sposób, by zadziwił, zafascynował młodych

${ }^{85}$ Por. Jan Paweł II, Głoszenie Chrystusa waszym powołaniem, 3; S. Wielgus, Kościół katolicki dziś. Zagrożenia, ich przyczyny oraz drogi wyjścia, s. 16.

${ }^{86}$ Por. R.J. Neuhaus, Człowiek nie jest skazany na klęskę, s. 179.

${ }^{87}$ Por. Jan Paweł II, Głoszenie Chrystusa waszym powołaniem, 2.

88 Por. NMI 40.

${ }^{89}$ Por. A. Offmański, W kierunku katechezy ewangelizacyjnej, s. 210. 
i pozyskał ich dla wiary Chrystusowej ${ }^{90}$. Wszak obszerna, rzetelna wiedza o przedmiocie miłości jest niezbędna o tego, by w razie potrzeby skutecznie stawać $\mathrm{w}$ obronie tego, kogo się miłuje. Tej prowadzonej z ufnością i twórczą inicjatywą działalności misyjnej nie można powierzyć jedynie wąskiej grupie specjalistów, ale będzie ona wymagać odpowiedzialnego udziału wszystkich członków Ludu Bożego, albowiem chrześcijaństwo jest ze swej natury misyjne, a otwarcie się na niewierzących jest częścią ewangelizacyjnej misji Kościoła ${ }^{91}$.

Pomimo iż wiele $\mathrm{w}$ ostatnich dziesiątkach lat uczyniono, by Biblia stawała się czytelna dla każdego chrześcijanina, trzeba stwierdzić, że w świadomości wielu chrześcijan pozostaje ona wciąż jeszcze księgą niewiele dla nich znaczącą ${ }^{92}$. Wielu ludzi obecnie jest skłonnych coraz bardziej wierzyć horoskopom czy krążącym przepowiedniom niż Ewangelii ${ }^{93}$. Można też $\mathrm{z}$ dość dużym prawdopodobieństwem stwierdzić, że wielu wierzących ma z Biblią raczej niewielki kontakt. Jeszcze ciągle za mało zna się u nas Pismo św., za mało się je studiuje w oparciu o zasady współczesnej hermeneutyki biblijnej. Większość zazwyczaj spotyka się z jej tekstami tylko podczas sprawowanej Eucharystii bądź innych czynności liturgicznych. Zatem jeśli katolikom zarzuca się czasem niedostateczną znajomość Biblii, to te zarzuty są niestety słuszne, między innymi dlatego, że katecheci katoliccy bywają nie dość ubiblijnieni. Ten brak zainteresowania Pismem świętym jest jednym $\mathrm{z}$ bardziej jaskrawych przejawów laicyzacji naszych czasów. Słowo nie wydaje owoców, a to dlatego, że przyjmuje się je w sposób bardziej intelektualny niż mądrościowy, bardziej spekulatywny niż poznawczy, bardziej refleksyjny niż modlitewny. Biblia wskazuje na potrzebę postawy aktywnej, ale na pewno pozbawionej zarozumiałości ${ }^{94}$. Oparciem i drogowskazem na drodze działalności misyjnej jest dla współczesnych chrześcijan świetlany przykład licznych świadków wiary. Tym bowiem, co stanowi tajemne źródło i nieomylną miarę apostolskie-

${ }^{90}$ Por. J. Kochel, Katecheza ewangelizacyjna w nauczaniu C.M. Martiniego, s. 99.

${ }_{91}$ Por. NMI 40-41.

92 Por. Z. Marek, Biblia w katechetycznej postudze słowa, s. 104.

${ }_{93}$ Por. W. Kawecki, Jubileusz chrześcijaństwa czasem odnowienia wiary i świadectwa, s. 86.

${ }^{94}$ Por. E. Bianchi, Przemodlić słowo, Kraków 1999, s. 27; W. Kubik, W poczuciu odpowiedzialności za wychowanie religijne, s. 26. 
go zaangażowania oraz misyjnego zapału Kościoła, jest jego świętość ${ }^{95}$. Świętość to najprostsza i najbardziej pociągająca droga, na której można bezpośrednio doświadczyć, jak piękna jest prawda, jak wyzwalającą moc ma miłość Boża i jaka jest wartość bezwarunkowej wierności wobec wszystkich wymogów prawa Pańskiego, nawet w najtrudniejszych okolicznościach ${ }^{96}$. Mimo wrogości otoczenia i prześladowań, składając niejednokrotnie najwyższe świadectwo krwi, ukazali, że można żyć Ewangelią. To wymowne orędzie, przemawiające bez słów, jest żywym objawieniem oblicza Chrystusa i tajemnicy Jego Kościoła ${ }^{97}$.

Życie świętych nie jest tylko prawdziwym wyznaniem wiary i zachętą do przekazywania jej innym, ale także uwielbieniem Boga i Jego nieskończonej świętości. Święty jest najwspanialszym świadectwem godności otrzymanej przez ucznia Chrystusa. Przez świadectwo życia, wielkodusznie i z radością ofiarowanego za Chrystusa i za braci przyczyniali się do tego, że Jego imię było coraz powszechniej znane i kochane ${ }^{98}$. Kościół, stosując mądrze zasady swej pedagogii moralnej, zawsze zachęcał wierzących, aby w postaciach świętych mężczyzn i kobiet szukali i znajdowali wzór, moc i radość życia zgodnego z przykazaniami Bożymi i z ewangelicznymi błogosławieństwami. Swoim przykładem niejako wskazali nam drogę ku przyszłości, nie pozostawiając innej drogi, jak tylko z pomocą łaski Bożej pójść ich śladami w okazywaniu ofiarnej miłości Chrystusa poprzez wszystkie swoje postawy i czyny ${ }^{99}$.

Streszczenie. Potrzeba posługi miłości (caritas) jest szczególnie nagląca w czasach współczesnych, gdy kultura śmierci tak agresywnie atakuje kulturę życia i często wydaje się nad nią przeważać. Dałem wam [...] przykład, abyście i wy tak czynili $(\mathrm{J} 13,15)$. Słowa te określają stale aktualne wyzwanie dla całej wspólnoty Kościoła - wezwanie do dawania świadectwa miłości przynoszącej wyzwolenie (zbawiającej). Tego świadectwa miłości, jedności i trwania we wspólnocie potrzeba dzisiaj światu, aby ludzie widzieli nasze dobre uczynki i chwalili Ojca, który jest w niebie (por. Mt 5,16). Każdy chrześcijanin wnosi w tę wspólnotę własny wkład, swoje talenty, zależnie od powołania i roli, jaką ma do

\footnotetext{
${ }^{95}$ Por. ChL 17.

96 Por. VS 107.

97 Por. NMI 41; ChL 16.

${ }_{98}$ Por. VS 107; ChL 16; Jan Paweł II, Głoszenie Chrystusa waszym powołaniem, 3.

99 Por. NMI 41; VS 107.
} 
spełnienia. Jedność w różnorodności, a zarazem świętość to wielkie bogactwo Kościoła, zapewniające mu ciągły i dynamiczny rozwój.

Kościół jest powszechny, a jego misja zbawcza zawiera w sobie cechę uniwersalności, dlatego ewangelizacja jest działaniem globalnym i dynamicznym, które obejmuje wszystkich chrześcijan uczestniczących w prorockiej, kapłańskiej i królewskiej misji Chrystusa. Jej stałe elementy to przepowiadanie Dobrej Nowiny, celebracja liturgii oraz posługa miłości. Ewangelizacja jest aktem głęboko eklezjalnym i stąd domaga się udziału wszystkich pracowników Ewangelii - każdego według właściwego mu charakteru i posługi.

Słowa kluczowe: świętość; łaska; naśladowanie Chrystusa; słowo Boże; ewangelizacja; miłość zbawcza.

Abstract. Quality of life - still relevant issue. Ministry of love (caritas) is especially pressing today when the culture of death attacks the culture of live so aggressively that it often seems to dominate. I set you [...] the example for you to follow (J 13:15). These are the words which determine the ever topical challenge for the whole Church community - an appeal to give a testimony of saving love which brings freedom. This testimony of love, unity and community is what the world needs today, so that people could see our acts of charity and praise the Father who is in heaven (cf. Mt 5:16). Every Christian makes a contribution to this community of his talents depending on his vocation and role which is supposed to fulfill. Unity in plurality and sanctity are Church's great wealth ensuring its permanent and dynamic development.

The Church is universal and its saving mission contains a feature of universality and that is why evangelization is a global and dynamic activity which comprises all Christians participating in prophetic, pastoral and royal mission of Christ. Its constant elements are preaching Good News, celebration of liturgy and service of love. Evangelization is a profoundly ecclesiastical act and therefore requires the involvement of all workers of Gospel - everyone in accordance with his appropriate character and service.

Key words: sanctity; grace; imitation of Christ; word of God; evangelization; saving love.

\section{BIBLIOGRAFIA}

Augustyn J., Świat naszych uczuć, Kraków 2001.

Bianchi E., Przemodlić słowo, Kraków 1999.

Frossard A., Bronię papieża, Warszawa 1995.

Góralczyk P., Sumienie a prawda $i$ wolność, „Communio” 2000, nr 1, s. 95-107.

Guardini R., Wolność - łaska - los, Kraków 1995.

Jan Paweł II, Adhortacja apostolska „Redemptoris Custos”, w:Jan Paweł II, Adhortacje apostolskie, Kraków 1996, s. 379-406. 
Jan Paweł II, Adhortacja apostolska „Christifideles laici”, w: Jan Paweł II, Adhortacje apostolskie, Kraków 1996, s. 345-480.

Jan Paweł II, Dar i tajemnica, Kraków 1996.

Jan Paweł II, Droga do dojrzałej wiary. Homilia wygłoszona do wiernych diecezji Nola (23 V 1992), 6, „L'Osservatore Romano” - wydanie polskie 1992, nr 7, s. 21-22.

Jan Paweł II, Ecclesia in Africa. Posynodalna adhortacja apostolska o Kościele w Afryce i jego misji ewangelizacyjnej u progu Roku 2000 (1995), w: Nauczanie Ojca Świętego Jana Pawła II. Komputerowy zapis dokumentów papieskich. Wersja 1.0, Wydawnictwo M, Kraków 1999.

Jan Paweł II, Encyklika „Dominum et vivificantem”, w: Jan Paweł II, Encykliki, Kraków 1996, s. 187-256.

Jan Paweł II, Encyklika „Veritatis splendor”, w: Jan Paweł II, Encykliki, Kraków 1996, s. 531-637.

Jan Paweł II, Głoszenie Chrystusa waszym powołaniem. Homilia z okazji jubileuszu katechetów i nauczycieli religii, „Katecheta” 2001, nr 4, s. 4-6.

Jan Paweł II, List do kapłanów na Wielki Czwartek 2002 r., Ząbki 2002.

Jan Paweł II, Modlitwa, wezwanie, odpowiedź: trzy podstawy powołania. Orędzie na Światowy Dzień modlitw o powołania z 6 I 1979, w: Nauczanie Ojca Świętego Jana Pawła II. Komputerowy zapis dokumentów papieskich. Wersja 1.0, Wydawnictwo M, Kraków 1999.

Jan Paweł II, Novo millennio ineunte. List apostolski, Poznań 2001.

Katechizm Kościoła Katolickiego, Poznań 1994.

Kawecki W., Jubileusz chrześcijaństwa czasem odnowienia wiary i świadectwa, „Homo Dei” 1999, nr 4, s. 85-96.

Kilpatrick W. K., Psychologiczne uwiedzenie, Poznań 1997.

Kochel J., Katecheza ewangelizacyjna w nauczaniu C. M. Martiniego, Opole 1999.

Komitet do Spraw Dialogu z Niewierzącymi Rady Konferencji Episkopatu Polski do Spraw Dialogu Religijnego, Niewierzacy w parafi - sugestie duszpasterskie, „Wiadomości KAI" z 8 VII 1999 r., s. 18-21.

Kubik W., W poczuciu odpowiedzialności za wychowanie religijne, „Horyzonty wiary” 1991, nr 7, s. 15-28.

Lewandowski J., Drogi współczesnego człowieka do „źródła” życia, Warszawa 2004.

Lewek A., Idea i sens nowej ewangelizacji, „Studia Theologica Varsaviensia” 32 (1994) z. 1, s. 45-107.

Lobkowicz N., Przekazywanie wiary, w: Podstawy wiary. Teologia, Kolekcja „Communio”, t. 6, Poznań 1991, s. 202-211.

Marek Z., Biblia w katechetycznej posłudze słowa, Kraków 1998.

Martini C. M., Ludu mój, wyjdź z Egiptu, Kraków 1989.

Neuhaus R. J., Człowiek nie jest skazany na klęskę, „Fronda” 2000, nr 21-22, s. $174-183$.

Offmański A., W kierunku katechezy ewangelizacyjnej. Polska katecheza młodzieżowa w latach 1945-2000, Szczecin 2000. 
Olejnik S., Teologia moralna fundamentalna, Włocławek 1998.

Paweł VI, Adhortacja apostolska „Evangelii nuntiandi”, „Chrześcijanin w świecie” 1976, nr 45 , s. $20-56$.

Przesłanie końcowe Światowego Kongresu Katolików Świeckich. Czujemy się odpowiedzialni za formacje $i$ wychowanie w wierze, „L'Osservatore Romano” - wydanie polskie 2001, nr 2, s. 42.

Quist M., Modlitwa i czyn, Warszawa 1984.

Ratzinger J., Duch liturgii, Poznań 2002.

Ratzinger J., Granice dialogu, Kraków 1999.

Ratzinger J., Nowa ewangelizacja, „L'Osservatore Romano” - wydanie polskie 2001, nr 6, s. 35-39.

Ratzinger J., O naturze kapłaństwa, „Pastores” 1998, nr 1, s. 27-38.

Ratzinger J., O nihilizmie, piekle i kryzysie w Kościele, „Fronda” 1999, nr 15-16, s. 6-21.

Ratzinger J., Prawda i sumienie, „Ethos” 1991, nr 15-16, s. 171-184.

Ratzinger J., Prawda, wartości, władza, Kraków 1999.

Ruini C., Pierwszeństwo łaski. Refleksje nad Listem apostolskim „Novo millennio ineunte”, „L'Osservatore Romano” - wydanie polskie 2002, nr 7-8, s. 58-59.

Santorski A., Droga życia wewnętrznego, Warszawa 1997.

Siemieniewski A, „Liczyć na moc Ducha”, „W drodze” 2002, nr 3, s. 8-21.

Solak A., Sytuacja wychowawcza szkoły w kontekście katechezy, w: Katecheza wobec wyzwań współczesności, red. R. Czekalski, Płock 2001, s. 119-129.

Stefański J., Liturgia źródłem i szczytem Kościoła, Gniezno 1993.

Synod Biskupów, Specjalne Zgromadzenie poświęcone Afryce, Lineamenta.

Tomasik P., Nauczanie religii w publicznym liceum ogólnokształcacym wobec założeń programowych polskiej szkoły, Warszawa 1998.

Wielgus S., Kościół katolicki dziś. Zagrożenia, ich przyczyny oraz drogi wyjścia, „Nasz Dziennik", 16-17 XI 2002, s. 11-16.

Wolicki M., Dojrzała osobowość, dojrzałe sumienie, Wrocław 2000.

Yanguas Sanz J. M., Moralność cnót czy moralność obowiązków?, „Communio” 2000, nr 5, s. 3-25. 